\title{
A catalog of the types of Carabidae sensu lato (Insecta, Cóleoptera, Adephaga) deposited in the Museo Argentino de Ciencias Naturales, Buenos Aires
}

\author{
Axel O. BACHMANN
}

Entomology Division, Museo Argentino de Ciencias Naturales «Bernardino Rivadavia», Av. A. Gallardo 470, C1405DJR Buenos Aires, Argentina. Researcher of the Consejo Nacional de Investigaciones Científicas y Técnicas. email: bachmann@bg.fcen.uba.ar

\begin{abstract}
The type specimens (all current categories) of Carabidae $s . l$. deposited in this Museum are listed; 101 names are recorded, 59 of them represented here by name-bearing types ('primary' types), two of them dubious. The family is taken in its broadest sense (including the Cicindelinae, Paussinae, and other groups sometimes considered as separate families). The species and subspecies names were alphabetically filed, followed by the generic ones as they were spelled in the original publication (or the generic and specific names in the case of subspecies and varieties). Later combinations and/or current binomina are mentioned insofar as these are known to the author. Two lists are added: 1 . of specimens labelled as types of names not found in the literature, and presumably not published, and 2. of specimens labelled as types, but not originally included as such, and published or not after the original description.
\end{abstract}

Key words: Carabidae, type specimens, Argentina.

A catalog of the typical specimens (all current categories) of species of Carabidae s. $l$. held in the Entomological Division of this Museum is presented, referred to 101 names: 25 holotypes, 56 syntypes (one of them dubious) of 33 names, 1 lectotype, 110 paratypes (which include 1 allotype) and 3 paralectotypes; 59 of these 101 names are here represented by name bearing types ('primary types').

The family is here taken in its broadest sense, including the Cicindelinae, Paussinae, and other groups sometimes considered as separate families.

Specific and subspecific names are alphabetically entered, as is usual in type specimen catalogs; each name is followed by the generic one (and subgeneric one when mentioned) spelled as it was in the original binomen, or by the generic and specific ones in the case of subspecies or varieties; an abbreviated bibliographic citation follows, as well as a listing of the types, if these were mentioned, beginning with those deposited in this Museum. An account of the type specimens actually housed here follows, with their label data. According to the International Code of Zoological Nomenclature (4th edition, 1999), allotypes are not 'name bearing types'. If the country is not mentioned, Argentina is meant; in every other case, the country is mentioned first. Some specimens bear a registration number, entered in the Entomology Division register; numbers under 10000 correspond to the old general register of the Museum. Later nomenclatural or taxionomical changes are added, insofar these are known to the author.

For the identification of types not formally designated in the original publication (art. 72.4 of the Code), evidences from the labels, as they were written by authors of names in the collections examined are considered. When the authors did not formally designate a holotype, or its equivalent, and did not mention the number of the specimens examined, it is assumed that they had a series of syntypes (recommendation $73 \mathrm{~F}$ of the Code), eventually 'unique syntypes'.

Some specimens in the collection are labelled as types, of names not found in the literature, and assumed not to have been published. These names are probably not available in the sense of the Code; however, in order to assist in future research, they are listed separately.

Specimens labelled as types, but not included in the original publication, and specimens designated as types after the original publication date, published or not, cannot be accepted as included in the type series; however they are included in a third list, also in order to assist in future research. 
Bruch used to copy the specific names of the types on his own labels, most of them with a red frame (a few with a green frame), and to add beneath, to the same pin, a small, folded piece of paper with the same name in the respective author's own hand, probably cut from a letter; frequently only a part of the genus name, and/or a part of the author name are readable.

Some specimens in the Bruch collection are labelled as 'cotypes' of species described by Jensen Haarup, whose collection is housed in the Zoologisk Museum of Köbenhavn (Danmark); probably most of the "primary' types are therein. As Jensen Haarup did not state how many specimens he had examined, they must be considered as syntypes. I suspect that some of the 'cotypes' in our Museum were not even included in the typical series, but it is not possible to assure their condition. In order to assist in future research, I include them in the present paper as syntypes or as paratypes, according to the context (Bruch used the term 'Cotypus' sometimes in the sense of syntypus and sometimes in the sense of paratypus).

This Museum is identified as MACN. Repositories of other types are identified as follows: $\mathbf{A B C}$, A. Breyer coll., in MACN; AC, Andrews coll., London, UK; AMNH. American Museum of Natural History, New York, USA; BC, M. Bänninger coll., Germany; BEC, C. Berg coll., in MACN; BM, The Natural History Museum, London, UK; BRC, C. Bruch coll., in MACN; CAS, Calffornia Academy of Sciences, San Francisco, USA; CSC, A. Campos Seabra coll., Brasil; DC, E. Dallas coll., in MACN; DEI, Deutsches Entomologisches Institut, BerlinDahlem, Germany; DZC, Departamento de Zoología, Universidad de Concepción, Chile; FAS, Facultad de Agronomía, Universidad de Chile, Santiago; FIML, Fundación e Instituto Miguel Lillo, Tucumán, Argentina; HB, H. Burmeister coll., in MACN; HC, W. Horn coll., Germany; IAD, IADIZA, Instituto Argentino de Investigación de las Zonas Aridas, Mendoza, Argentina; IBSP, Instituto Biologico, São Paulo, Brasil; IEEA, Instituto de Ecologia e Experimentação Agricola, Rio de Janeiro, Brasil; IPCN, Instituto Patagónico de Ciencias Naturales, San Martín de los Andes, Neuquen Prov, Argentina; IZG, Instituto de Zoología General y Sistemática, Santiago, Chile; JAC, L. Jiménez-Asúa coll., now in Havanna, Cuba; JB, J. Brèthes coll., in MACN; JH, JensenHaarup coll, in Zoologisk Museum, Köbenhavn, Danmark; JMC, J. Mateu coll., Almería, Spain; LC, M. Liebke coll., Germany; LPC, L. Peña coll., Santiago, Chile; LTC, C. Lizer y Trelles coll., in Facultad de Agronomía, University of Buenos Aires, in part in MACN; MB, Museum Bern, Switzerland; MC, A. Martínez coll., in part in MACN;
MCH, Museo Nacional de Historia Natural, Santiago, Chile; MCSN, Museo Civico de Scienze Naturale, Genova, Italy; MD, Museu Dundo, Angola; MHNS, Museo Nacional de Historia Natural, Santiago, Chile; MLP, Museo de La Plata, Argentina; MNHN, Muséum National d'Histoire Naturelle, Paris, France; MS, Stettiner Museum, Germany; MTD, Museum für Tierkunde, Dresden, Germany; MV, Museo de la Universidad de Chile, Valparaíso; MZSP, Museu de Zoologia, São Paulo, Brasil; NC, J. Nègre coll.; OC, E. Ogueta coll., in MACN; PAN, Polska Akademya Nauk, Warshaw, Poland; PC, A. Prosen coll., Buenos Aires, Argentina; RC, Reichensperger coll., Germany; RIC, Richter coll., at MLP; SCG, Steinbach coll., Germany; SCI, Straneo coll., Italy; SEM, Strickland Entomological Museum, Edmonton, Alberta, Canada; STC, Stevenin coll., in MACN; TC, J. Tremoleras coll., Montevideo, Uruguay; ZMB, Zoologisches Museum, Berlin, Germany; ZMH, Zoologisches Museum, Hamburg, Germany.

I am very grateful to Dr. Sergio Roig-Junent (IADIZA) for highly valuable suggestions regarding a prior version of the present paper, and for careful revision and updating of binomina and synonymies.

\section{CATALOG OF THE TYPES}

affinis [Obadius]. Tremoleras 1931: 247. Uruguay: Cerro Largo Dept.: Cañada de los Burros, 2 ex., one of them holot.; Treinta y Tres Dept., 2 ex. TC.

1 parat., pinned, Uruguay: Cerro Largo: Banado de los Burros, "Cotypus" on pink paper; "Obad. insignis Burm. = var. affinis Trem. = nec. spec. / C. Bruch determ." handwr. by Bruch, ex BRC.

andinus [Tachys]. Jensen-Haarup 1910: $553-554$. Mendoza Prov. "not uncommon".

1 paralectot. glued to a card, Mendoza, "Cotypus" on pale green paper, ex BRC.

Notes: Transferred to Pericompsus (Pericompsus), and lectot. and paralectot. design. by Erwin $(1974:$ 9, 10,65, f. 96, 102, 107); lectot. in JH.

angusticollis [Eurysoma]. Burmeister 1885; 329. Paraguay.

2 synt., pinned, Paraguay, and without label respectiv., ex $\mathbf{H B}$.

Notes: On the bottom of the drawer a label, handwr. by Burmeister reads "longicollis Nob./ Paraguay" (transcription error?). Recorded under Brachygnathus by Csiki (1929: 354). Eurysoma Déjean 1881 is a junior synonym of Brachygnathus Perty 1830. 
argentina [Ega]. Brèthes 1916: 464-465. Several ex. from Jujuy, sub 7274 .

4 synt, glued to cards, on 2 pins $(1+3$, the one with 3: "7274"), Jujuy, ex JB.

argentinica [Propionycha]. Liebke 1928: 215.2 couples from Buenos Aires Prov, BRC.

2 synt. glued to cards, B. Aires Prov., "Type" on pink paper; "Propionycha/argentinica / det. M. Liebke Hamb" handwr. by Liebke, cut, ex BRC.

argentinicum [Zuphium]. Liebke 1933: 462, 464. 465. 4 ex. from Argentina: type from Buenos Aires, BRC, 1 ex. from Rio Colorado, LC; 1 ex. from Buenos Aires, TC; 1 ex. from Mendoza, MTD.

Holot. glued to a card, B. Aires Prov., "Type" on pink paper; "Zuphium/argentinicum/Type/ det. M. Liebke Hamburg" handwr. by Liebke, ex BRC.

argentinicus [Pseudaptinus [(Enaphorus)]]. Liebke 1929: 351, 1 f. 2 ex. from Buenos Aires Prov., ex BRC, cotype in LC lergo type in BRC).

Holot. glued to a card, B. Aires Prov., "Foto" (Bruch); "Type" on pink paper; "Pseudaptinus / argentinicus Lbk. / det. M. Liebke Hamb" handwr. by Liebke, cut, ex BRC.

Notes: There are 2 further ex., labelled "Cotypus" by Bruch, not mentioned in the original publication (see under Specimens non included in the original series, below). Recorded under Brachynus (Brachynaptinus) by Csiki (1933: 1628), and under Pseudaptinus by Reichardt (1967a: 267). Currently included in Thalpius.

arrowi [Colliuris (Procolliuris)]. Liebke 1930: 707. 7 ex. from Santa Fe Prov.: río San Javier, Estancia La Noria; 1 ex. from Entre Rios Prov: Santa Elena, all in BM; 1 ex. from Tucumán Prov, in BRC.

1 synt. glued to a card, Tucumán Prov.: Famaillá, "Kotype" on pink paper; "Odacantha / arrowi/ Lbk. / cet. M. Liebke Ham." handwr. by Liebke, folded; "Calophaenoidea / arrowi / Lbk. [handwr.] / C. Bruch determ. [printed]" on white paper, remainings of black frame, ex BRC.

Notes: Odacantha Paykull 1798 is a junior synonym of Colliuris Degeer 1774, fide Liebke (1930). The label of Liebke seems to have been written much before the publication of the monography (1930). The label handwritten by Bruch is obviously an error for Colliuris arrowi; both species were described in the same paper. I have checked the original descriptions of both species with the specimen, which is clearly a species of Colliuris. asuai [Panagaeus (Hologaeus)]. Ogueta 1966: 8-10, f. 4, 7. Holot. 0 from Dominican Rep.: S. Domingo.

Holot. $\varnothing^{\prime}$ glued to a card, partially dissected and the parts glued to two further cards, S. Domingo.

australis [Cicindelidia trifasciata subsp.]. Peña \& Barría 1973: 188-189, f. 5-12, 17. Chile: Coquimbo Prov: Punta Teatinos; Aconcagua Prov; Coquimbo Prov.; holot. $\%$ and parat. in LPC; other parat. in AMNH, DZC, FAS, MHNS.

1 parat, pinned, Chile: Coquimbo: Punta Teatinos.

Note: Currently recorded as Cicindela (Plectographa) suturalis australis, C. trifasciata sensu Déjean non Fabricius is a misidentification for suturalis Fabricius 1798, as stated by Freitag \& Barnes (1989: 298).

bordoni [Platycerozaena]. Ogueta 1965b: 367 368, f. 4, 5. Holot. 9 from Venezuela: Aragua State: Caguá, OC.

Holot. o ghued to a card, dissected, and the parts glued to two further cards, Venezuela: Aragua: Caguá, ex $\mathbf{O C}$.

bosqui [sic] [Mimodromius (Cobosia)]. Mateu 1955: 97, f. 43, 44. Cotypes from Neuquen Prov: Zapala in MACN and FIML, from La Pampa Prov.: Pico, MC, from Río Negro Prov.: Choele-Choel, and Neuquen Prov: Plaza Huiral (sic), PC; from Buenos Aires Prov.: Solá Railway Station, and Mendoza, JMC.

2 synt. 32470 , glued to cards, one on its dorsum, one on its venter, the first one with dissected parts glued to another card, Neuquen Prov: Zapala, "Cotipo" on red paper; "Mimodromius / (Martinezia) / bosqui n. sp. / J. Mateu det." handwr. by Mateu, ex BRC, slide P.00178, sub M'84 in slide collection.

Notes: There is a further ex. from B. Aires Prov: San Blas, not mentioned in the original publication, 31793, labelled "Cotipo" on red paper (see under Specimens non included in the original series, below). The species was named in honour of Mr. Juan Bosq; this does not follow from the specific epithet.

breyeri [Physea]. Ogueta 1963: 116-118, f. 2, 7, 9, 13. Brasil: Minas Gerais State: Acesita, holot. $O$ in CSC; 1 $\%$ parat. OC; allot. $0^{*}$ from Brasil: Goiás State, MZSP; $1 \%$ parat., as the holot, $\mathrm{OC} ; 1 \%$ parat. from Brasil: $\mathrm{S}$. Paulo State: Anhangaby, MZSP.

Holot. , , 1 parat. glued to cards, Brasil: M. Gerais: Acesita, ex $\mathbf{C S C}$, and ex $\mathbf{O C}$ respectively.

bruchi [Cnemalobus]. Roig-Juñent 1993c: 290-291, f. $10,19,27,30,31,39$. Parat. from Catamarca Prov.: 1 
O" Catamarca; $20^{7}$ Belén: La Ciénaga; 107 Las Conchas, $10^{\circ}$ Quebrada, $3200 \mathrm{~m}$ altit., $10^{\circ}$ Agua Amarilla, $1 \sigma^{\circ}$ Santa María; 2 parat. without locality label, all in MACN. Holot. $\sigma^{\circ}$, allot. $\&$, Tucumán Prov.: Gobernador Garmendia, ex MLP; other parat. in IAD and MLP.

7 parat., pinned, Catamarca Prov., ex BRC: 1 Catamarca, 1 Quebrada, 1 Las Conchas, 2 Belén: La Ciénaga, 1 Agua Amarilla, 1 Santa María; 2 parat., pinned, without locality label, ex BRC and ABC.

bruchi [Cteatus]. Liebke 1936a: 302. 3 ex. from Buenos Aires Prov.: Rosas in BRC and $\mathrm{LC}$.

2 synt. glued to cards (one on its venter, one on a side), B. Aires Prov: Rosas, "Cotypus" on red paper; "Kteatus / bruchi lbk. / Kotype / M. Liebke determ." handwr. by Liebke, ex BRC.

bruchi [Galerita]. Liebke 1932: 415, 417.2 O' from Misiones Prov., type in BRC.

Holot., pinned, Misiones Prov., "Type" on pink paper; "Gallerita / bruchi Lbk. / det. M. Liebke Hamb" handwr. by Liebke, cut, ex BRC.

bruchi [Lebia]. Lieble 1936a: 302-303. 2 ex. from Buenos Aires in BRC and LC.

1 synt. glued to a pointed card, B. Aires Prov, "Typus" on red paper; "Lebia/bruchi Lbk. / M. Liebke determ." handwr. by Liebke, ex BRC.

bruchi [Leptotrachelus]. Liebke 1928: 191. 2 ex. from Corrientes Prov: San Roque, BRC.

1 synt. glued to a card, Corrientes Prov, "Type" on pink paper; "Leptotrachelus / bruchi Lbk. / det. M. Liebke Hamb" handwr. by Liebke, cut, ex BRC.

bruchi [sub Bruchi] [Propionychal. Liebke 1928: 209. Buenos Aires Prov., "ein Pärchen" (a pair) in BRC.

I synt. and 2 parat.? glued to cards, B. Aires Prov., -"Type" (on pink paper); "Cotypus" (on pale green paper) respectiv., the "type", in addition, "Propionycha / Bruchi Lbk. / det. M. Liebke Ham" handwr. by Liebke, cut, ex BRC.

Note: one or both "cotypes" might not be types, as Liebke mentions a pair, and both "cotypes" bear identification labels handwr. by Bruch, not by Liebke.

bruchi [Scarites]. Bänninger 1932: 210-211. 3 ex. from Mendoza Prov: Potrerillos, type in BRC; 2 cotypes BC; 1 ex. from Catamarca Prov: La Ciénaga, BRC; 2 ex. from Mendoza Prov, BM; 2 ex. from Tucumán, BC.

Holot. pinned, Mendoza Prov." "Typus" on pale green paper; "Scarites / Bruchi n. sp. / 8.1926/ Bänninger det. / in Gruppe I.A.2.a/Chd. Monographie" handwr. by Bänninger, ex BRC.
Notes: There is, in addition, $1 \mathrm{ex}$, from Catamarca Prov.: La Ciénaga, labelled "Cotypus"; it was mentioned, but it seems not to have been intended to conform the typical series (see under Specimens non included in the original series, below). Included by Bänninger (1938) in Scarites (Scarites).

brunneus [Pseudaptinus (Thalpius)]. Liebke 1934: 374, 383-384. 2 ex. from Buenos Aires Prov.: Rosas, 1 of them in BRC, 1 LC: 2 without locality, 1 of these is the type, ZMH.

1 parat. glued to a card, B. Aires Prov: Rosas, "Kotype" on pink paper; "Pseudaptinus/ brunneus Lbk. / Kotype / M. Liebke determ." handwr. by Liebke, ex BRC.

Note: Currently included in Thalpitus.

bucephala [Megacephala (Phaeoxantha)], Horn 1909:284m286. o", of from "Tukumán" 28.I.1899, Girard, and from Santiago del Estero, Steinbach.

1 o' synt.? pinned, Tucumán Prov., "Cotypus" on pale green paper, ex BRC.

Notes: The specimen lacks both date of collection and name of collector, which were mentioned in the original paper, which renders its syntype condition dubious. Sometimes included in Megacephala (Tetracha).

calchaquensis [Barypus]. Roig-Junent 1993b: 18 20, f. 1. 6, 21, 29, 35, 42, 76-84. Parat. from Salta Prov: Cuesta del Obispo; 4 from Salta, ex BRC; 3 from Catamarca Prov.: Chafinar (sic) (2 of them ex BRC). Holot. $0^{7}$, allot. \%, parat. from Salta Prov.: Cuesta del Obispo in MLP; other parat, in FIML.

10 parat, pinned: 2 Salta; 2 Salta: Cuesta del Obispo: Piedra del Molino; 2 Catamarca; 1 Catamarca Prov.: Chafiñán; 3 Tucumán, all ex BRC.

castanea [Lebia (Loxopeza) striata var]. Liebke 1936a: 303. 1 ex. from Misiones Prov: S. Ignacio in BRC; 1 ex. Brasil: $R$. de Janeiro in $\mathbf{L C}$.

1. synt. glued to a card, Misiones: S. Ignacio, "Typus" on orange paper; "Lebia striata / var. castanea Lbk. / M. Liebke determ." handwr, by Liebke, ex BRC.

catamarcensis [Pericompsus]. Roig-Juñent \& Scheibler [accepted for publication] Catamarca Prov.: $28 \mathrm{~km}$ SE of Tinogasta, 20.X.1997, holot. in IAD, 16 parat. Id, IAD, AMNH, FIML, MLP, SEM; other parat. from Catamarca Prov: S. Fernando, and Betén in IAD.

1. parat. glued to a pointed card, Catamarca, $28 \mathrm{~km}$ SE Tinogasta, 20.X.1997, leg. S. Roig, "Paratypus" printed on red paper; "Pericompsus catamarcencis [sic]/ Roig-Juñent \& Scheibler" printed on white paper. 
chacoensis [Lebia]. Liebke 1935: 166-167. I ex. from Santiago del Estero in BRC. Type from Brasil: M. Grosso State: Corumbá, LC; 1 ex. from Argentina: Chaco de Santa Fe, LC; 2 ex. from Santiago del Estero Prov: Banderas; 1 ex. from Santa Fe Prov: Las Garzas, MNIN.

1 párat. glued to a card, S. del Estero Prov, "Typus" on red paper; "Lebia/chacoensis Lbk. / M. Liebke determ." handwr, by Liebke, ex BRC.

Note: Currently iricluded in Lebia (Lebia).

chaudoiri [sub Chaudoiri] [Bembidium]. Berg 1883: 395. 1 ex. from Narra-Có, = luridipenne Chaudoir in coll., non Schaum 1860.

Holot. glued to a card, "Narra-Co" (handwr. on green paper), "Typus" on greenish gray paper; "Bembicidium / Chaudoiri / Berg" handwn., with a red frame, ex BEC.

Note: Recorded as Bembidion Chaudoirianum by Csiki (1928: 159) nom, nov. pro chaudoiri Berg non Motschulsky, and as Notaphus (Notaphus) chaudoirianus by Jeannel (1962: 623, 626).

chubutensis [Barypus]. Rờ-Juñent 1993a: 98-99, f. 7, 18, 26, 34,90-98. 2 parat. from Chubut Prov. Holot. O MLP; parat. in IPCN and MLP.

2 parat. glued to pointed cards, with a glass microvial, Chubut.

Note: Roig-Juñent (1993b) included this spe cies in Barypus (Cardiophthalmus).

comechingonensis [Barypus (Barypus)]. RoigJunent 1998b: $20-21, f$. 1, 7, 22, 30, 36, 43, 85-93. 5 parat. Córdoba Prov: Alta Gracia in BRC; 1 parat. Córdoba; 2 o San Luis; 1 parat. San Luis Prov.: El Durazno. Holot. $\sigma$, allot, several $\sigma^{\prime}$ parat. Córdoba Prov.: La Falda in MLP.

8 parat., pinned, Córdoba $(7$ of them Alta Gracia), ex BRC; 2 parat. on pointed cards, S. Luis; with a glass microvial.

Notes: There are two more paratypes than mentioned, but otherwise the labels seem authentic.

convexa [Ozaena]. Bänninger 1927: 195, 196-197. 1 ex. from Misiones Prov. in BRC; 1 o", 2 \& from Brasil: Mato Grosso State: Corumbá in BC; 1 ex. from Brasil: Pará State in BM; 3 ex. in MB.

1 synt., pinned, Misiones, "Typus" on pale green paper; "Ozaena/ convexa m. n. sp./6. 1916 /Bänninger det." handwr, by Bänninger, ex BRC.

convexipennis [Galerita]. Reichardt 1967b:55, 123, f. 60, 117, 118. Holot. $0^{7}, 2$ parat. Salta Prov: Abra de Minas in BRC. Other parat. in MLP, MZSP, CAS, NC.

Holot. $0^{*}, 2$ parat., pinned, with a glass microvial, Salta: Abra de Minas, the holot. "Galerita / convexipennis / Bruch / C. Bruch determ." handwr. by Bruch; "Galeritula / convexipennis n. sp./ Holotype $0^{*} /$ Reichardt det. 1965" handwr. by Reichardt; the paratypes labelled only by Reichardt, all ex BRC.

cordobana [Lia clavata var.]. Liebke 1936a: 304.2 ex. from Córdoba Prov., sierras (1 BRC, 1 LC).

1 synt., pinned, sierras of Córdoba, "Typus" on red paper; "Lia clavata/ var. cordobana Lbk. / M. Liebke determ." handwr. by Liebke, ex BRC.

Note: Recorded under Lebia by Madge (1967: 147); a synonym of Lebia (Chelonodema) clavata (Lieble 1929) fide Reichardt (1972: 25-26, f. 10, $13,31,50,70)$.

costalimai [Galerita]. Reichardt 1967b: 99-100, f. 88, 89, 95. 2 parat. from Tucumán. Holot. from Brasil: Sáo Paulo State: Boracéia, in MZSP; parat. in IEEA, PAN, NC.

2 parat. 4290, pinned, Tucumán Prov: Tafi Viejo, "Galeritula/costalimai, n. sp./ Paratype o / Reichardt det. 1965" handwr. by Reichardt.

cupreolimbata [Calleida]. Liebke 1936a: 301. Cotype from Chaco de Santa Fe in BRC; from Brasil: Säo Paulo in $L C$.

1 parat. glued to a card, Chaco de Santa Fe, "Calleida / cupreolimbata Lbk. / Kotype / M. Liebke determ." handwr. by Liebke, ex BRC.

Note: Recorded under Callida by Csiki (1932: 1439).

cyanea [Megacephala fulgida subsp.]. Horn 1905: 52. $0^{7}$, \% San Juan and Mendoza Prov.; Corralitos; name of Chaudoir in litt.

1. $\%$ synt. glued on its back to a card, Mendoza Prov, "Cotypus" on pale green paper; "Tetracha/ cyanea/W. Horn / Chd. i. litt." handwr, by Bruch, ex BRC.

Note: Recorded as Megacephala cyanea by Vidal Sarmiento (1966a: 16-17, f. 17, 18).

cylindricus [Cnemalobus]. Roig-Junent 1994: 1617, f. $7,24,38,49,50,57,61$. Parat. Chile: Coquimbo: $\$$ of Puerto Oscuro. Holot. $0^{*}$, allot. 9 in MLP; other parat. in $\mathrm{LAD}$ and DZC.

2 parat, pinned, Chile: Coquimbo Region, one of them with a glass microvial.

dentipenis [Barypus]. Roig-Junent 1993a: 97-98, f. $6,17,25,33,81-89.2$ parat. from Rio Negro Prov., in BRC. Holot. $0^{\prime}$, allot. 0 in IAD; parat. in ML.P.

2 parat. (1 pinned, 1 glued to a pointed card), with a glass microvial, R. Negro, ex BRC.

Note: Roig-Junent (1993b) included this species in Barypus (Cardiophthalmus).

deplanatus [Cnemalobus], Roig-Juñent 1993c: 292 294, f. 12, 21, 34, 35, 41, 43. 2 \& parat, Río Negro Prov: 
San Carlos de Bariloche. Holot. $\sigma^{\pi}$, allot, $\%$ in MLP; other parat. in MLP, IAD and IPCN.

2 parat., pinned, one of them with a glass microvial, Río Negro Prov.: S. Carlos de Bariloche.

dubium [Bembidium]. Jensen-Haarup 1910: 550w 551. Mendoza Prov., "not rare".

1 synt. glued to a card, Mendoza, "Cotypus" on pale green paper, and "Bembidium/ dubium/ J.-Hrp" handwr. by Bruch (not by Jensen-Haarup), ex BRC.

Notes: Recorded as Bembidion JensenHaarupi Csiki (1928: 161) nom. nov. pro dubium Jensen-Haarup non Heer. A synon. of Notaphiellus solieri (Gemminger \& Harold 1868: 421) nom. nov. pro Bembidium incertum Solier in Gay, 1849: 168-169 non dubium Motschulsky; of $B$. convexiusculum Solier 1849 ; of $B$. valdivianum Gemminger \& Harold 1868, and of B. varicolor Reed 1874, fide Jeannel (1962: 632-633).

engelharti [sub Engelharti] [Bembidium]. Jensen-Haarup 1910: 547-548. Mendoza, "not uncommon near streams, rivers and "lagunas".

1 synt. glued to a card, Mendoza Prov., "Cotypus" on pale green paper; "Bembidium / Engelharti / J.Hrp." handwr. by Bruch (not by Jensen Haarup), ex BRC.

Note: Recorded under Bembidion by Blackwelder (1944: 29), and under Peryphus (Antiperyphus) by Jeannel (1962: 647, 648, f. 226, 234).

feana [Calleida]. Liebke 1936a: 301. 2 ex. from Santa Fe Prov.: Rosario, in BRC and LC.

1 synt. glued to a card, S. Fe: Rosario, "Typus" on red paper; "Callida / feana / Lbk. Type / M. Liebke determ." handwr. by Liebke, ex BRC.

Note: Recorded under Callida by Csiki (1932: 1439).

fervida [Eurysoma]. Burmeister 1885: 332. Southern Córdoba.

1 synt., pinned, "Cordova", ex HB. On the bottom of the drawer two labels read: "Brachygnathus Port. / Eurysoma Dj." and "fervidus Burm. / Rep. Arg." handwr. by Burmeister, with a black frame.

Notes: Burmeister did not mention how many specimens he has seen, presumably only one. Recorded under Brachygnathus by Csiki (1929: 354). (Eurysoma Déjean 1831 is a junior synonym of Brachygnathus Perty 1830). A synonym of $B$. festivus Déjean fide Straneo (1951a: 4, 5), but seemingly a separate species.

fluvialis [Pseudaptinus (Thalpius)]. Liebke 1934: 374, 386-387. 1 ex. from Buenos Aires Prov., in BRC,
Type from Brasil: Mato Grosso State: Corumbá in LC; 1 ex. from Argentina: Santa Fe Prov: Villa Ana in BM,

1 parat. glued to a card, Prov. B. Aires, "Kotype" on pink paper; "Pseudaptinus / fuvialis Lbk. / Kotype / det. M. Liebke. Hamburg" handwr. by Liebke, ex BRC.

giaii [Barypus]. Roig-Junent 1993a: 96-97, f. 5, 16, 24, 32, 72-80.6 o, 1 o parat. Río Negro Prov; 1 \& Río Negro Prov.: Aguada de Avila; 20,1 \% Río Negro Prov: Nahuel Huapi, all in BRC. Holot. $\sigma^{\prime}$, allot. 7 , parat. in IAD, other parat. in MLP and IPCN.

11 parat. (6 pinned, 5 glued to pointed cards), all with glass microvials, R. Negro (3 Nahuel Huapi, 1 Aguada de Avila, 7 without precise locality), ex BRC.

Note: Included by Roig-Juñent (1993b) in Barypus (Cardiophthalmus).

glabra [Pseudomorpha]. Ogueta 1967: 221-222, f. 1. Holot. $\%$ from Santiago del Estero, in BRC.

Holot. $q$ glued to a card, dissected parts glued to a further card, S. del Estero Prov., ex BRC.

halfferi [Ozaena]. Ogueta 1965a: 83-87, £. 4, 14, 21, 29, 38. Holot. O from México: Veracruz State: Tlapacoyan, in $\mathbf{O C}$.

Holot. $\%$ glued to a card, with a glass microvial, México: Veracruz: Tlapacoyan, ex $\mathbf{O C}$.

horni [sub Horni] [Cicindis]. Bruch 1908: 499-500, f. $1-4.1$ ex., Córdoba.

Holot., pinned, with a plastic microvial, Córdoba, "Typus" on pale green paper; "Cicindis / Horni Bruch / C. Bruch determ." handwr. by Bruch, ex BRC.

Note: The specimen was relabelled, and redescribed by Kavanaugh \& Erwin (1991: 359, 362-365, many f.)

incequalis [Marsyas]. Straneo 1968: 222-223. Brasil: Goiás State: Jatahy, holot., allot. and parat. in MNHN; other parat. in MZSP, NC and SCI.

1 parat., pinned, Brasil: Goiás: Jatahy, "Paratypus / Marsyas / inaequalis / Stran." handwr. on red paper; "Marsyas / inaequalis m. / det. S. L. Straneo 1967" handwr. by Straneo on white paper.

insignis [Obadius]. Burmeister 1875: 341, 1 f. 1 ex. from Entre Rios Prov., near Concordia.

Holot., pinned, without labels, ex HB; on the bottom of the drawer two labels read: "Obadius/ Burm." and "insignis / Burm. / Entrerios" handwr. by Burmeister, with a black frame.

jacobseni [sub Jacobseni] [Bembidium]. JensenHaarup 1910: 552. Mendoza Prov., "common". 
1 synt. glued to a card, Mendoza Prov., "Cotypus" on pale green paper; "Bembidium / Jacobseni / J. Hrp." handwr. by Bruch, ex BRC.

Note: Recorded under Bembidion by Blackwelder (1944: 29), and under Notaphus (s. str.) by Jeannel $(1962: 624,626)$.

kulti [Feroniola]. Straneo 1952: 2, 3-4, f. 1. Bolivia: Cochabamba: Tunari Massif; types in SC; 1 parat. in MCSN.

1 parat. glued to a card, Bolivia: Cochabamba: Tunari Mass., "Paratypus / Feroniola kulti" on red paper; "Feroniola kulti n. sp. / Det. L.S. Straneo 194_[black ink] / Paratypus [red ink]" handwr. by Straneo on white paper.

linearis [Ozaena] Bänninger 1927: 195. 1 ex. from Catamarca in coll. Bruch. $30,1 \%$ Chaco de Santiago del Estero: Salado River, in BC.

1 synt., pinned, Catamarca Prov., "Ozaena linearis / Bänninger det. [obverse] / 9.1926 [reverse]" handwr. by Bänninger on white paper, cut, ex BRC.

lizeri [Zuphium]. Liebke 1933: 462, 465-466. 2 ex. (1 is the type), from Bolivia: Cuatro Ojos; 2 ex. from Bow likvia: Beni: 'Trinidad, in LTC and LC.

Holot. and 1 parat. glued to cards, Bolivia: Cuatro Ojos; 1 parat. on a card, Bolivia: Trinidad, "Type" and "Kotype" on pink paper; "Zuphium / lizeri / Lbk. Type [Kotype] / det. M. Liebke Ham. burg" handwr. by Liebke, all ex LTC.

lonae [sub Lonae] [Bembidium]. Jensen-Haarup 1910: 547. Mendoza Prov, "very common".

1 synt. glued to a card, Mendoza, "Cotypus" on pale green paper; "Bembidium/lonae/J.-Hrp." handwr. by Bruch, with a red frame, ex BRC.

Notes: Recorded under Bembidion by Csiki (1928: 161); a synon. of Nothonepha baptisatum Csiki (1928: 159) nom. nov. pro Bembidium elegans Solier (in Gay, 1849: 164-165) non Germar nec Stephens fide Jeannel (1962: 641). Recorded as Notonepha Lonai by Jeannel (1962: 641).

lunacarvalhoi [subluna-carvalhoi] [Homopterus]. Martínez \& Jiménez-Asúa 1965: 233-235, f. 1-4. Misiones Prov: S. Ignacio, holot. $O^{x}$ in MC, parat. $O^{\prime \prime}$ in JAC.

Holot. O" glued to a pointed card, dissected parts glued on a further pointed card, Misiones: S. Ignacio, ex MC.

martinezi [Cymindidius]. Mateu 1959:2-3, 4, f. $1 \mathrm{~A}$. Type $0^{*}$, Santa Cruz Prov: : San Julián, in BRC.

Holot. 53273 glued to a card, S. Cruz: S. Julián, "Holotypus" on red paper; "Cimindidius/ martinezi mihi / J. Mateu det." handwr. by Mateu, ex BRC.
Note: Mateu (1970) put Cymindidius in Mimodromius as a subgenus.

martinezi [Homopterus]. Luna de Carvalho 1963: 6, 11-12, f. 19-22. Holot. $\odot$ from Brasil: Pará State: Belém, in MC.

Holot. $\&$ on a minuten Nadel with a soft pith block, Brasil: Pará: Belém, ex MC.

martinezi [Ozaena]. Ogueta 1965a: 79-83, f. 3, 15, $22,30,37,41$. Holot. o7 Bolivia: Santa Cruz Dept.: Ichilo Prov: Buenavista, in OC; 1 O$^{7}$ parat. Bolivia: Riv. Songo, in MNHN.

Holot. $0^{x}$ glued to a card, dissected parts glued on two further cards, Bolivia: S. Cruz: Ichilo: Buenavista, ex OC.

mendocinum [Bembidium]. Jensen-Haarup 1910: 549. Mendoza Prov., "common".

4 synt. glued to cards, on 2 pins, Mendoza, "Cotypus" on pale green paper; "Bembidium / mendocinum / J.-Hrp." handwr. by Bruch with a red frame, ex $\mathbf{B R C}$.

Note: Recorded under Bembidion by Blackwelder (1944: 29), and under Peryphus (Chilioperyphus) by Jeannel (1962: 651, 652, f. 241).

mendocinus [Tachys], Jensen-Haarup 1910: 553. Mendoza Prov, "not rare".

1 paralectot. glued to a card, Mendoza, "Cotypus" on pale green paper; "Tachys / mendocinus / J.-Hrp." handwr. by Bruch, with a red frame, ex BRC.

Notes: Lectot. $O^{*}$ and 5 paralectot. from Mendoza, at JHC, design. by Erwin (1974: 7, 28, f. $27,32,46$ ), who synonymized this name with Pericompsus [(Eidocompsus)] metallicus Bates 1871, from Brasil: Rio de Janeiro, and designated lectot., in MNHN, and with Leiotachys humeralis Jeannel 1962, holot. $\%$ in MNHN.

mendozensis [Austroglyptolenus]. Roig-Junent 2003: 47-49, f. 1-12. Mendoza Prov.: Las Heras Dept: Agua de las Chilcas, holot. $O^{*}$ and several parat. in $I A D$; other localities in Mendoza and San Luis Prov., several parat. in IAD.

1 parat, pinned; a small disk of blue paper. Argentina: Mendoza Prov.: Agua de las Chilcas, Las Heras, III.1997, leg. S. Roig, "Paratypus" printed on red paper; "Austroglyptolenus mendozensis/ Roig-Juñent" printed on white paper.

mendozensis [Barypus]. Roig-Juñent \& Cicchino 1989: $210-212$, f. 1, 9, 20, 29, 30, 38, 88.93. 1 parat. Mendoza Prov: Fortín Malargüe. Holot. Mendoza Prov: F. Malargüe in IAD; other parat. from several localities, in IAD, MLP and FIML. 
1 parat. glued to a pointed card, with a glass microvial, Mendoza: Fortín Malargüe; 1 parat., pinned, with a glass microvial, Mendoza: Quebr. Villavicencio.

Note: Included by Roig-Juñent (1993b) in Barypus (Cardiophthalmus).

mendozensis [Cnemalobus]. RoiguJuñent 1993c: 297-299, f. $6,14,23,27,44,45,52.2$ ? parat. Mendoza Prov: Malargüe: Cueva de los Tigres, and $20 \mathrm{Km} \mathrm{W}$ of Agua Escondida respectively. Holot. $\sigma^{*}$, allot. $\&$ and 1 o parat. in MLP; other parat. in IAD.

2 parat., pinned, Mendoza Prov.: Agua Escondida, and Malargüe, respectively.

metallicus [Mimodromius]. Mateu 1.955: 86, f. 16, 17. Holot. $0^{7}$ and parat. Río Negro Prov: Bariloche. 1 parat. Neuquen Prov.: Victoria Lake (sic) in PC.

Holot. $0^{*}, 3$ parat. glued to cards, on 3 pins, the holot. with the genitalia glued on a further card, R. Negro: Bariloche, "Holotipo" and "Paratipo" on red paper; "Mimodromius s. str. / metallicus n. sp. / J. Mateu det." handwr. by Mateu.

Note: Currently included in Mimodromius (Mimodromius).

mimicus [Pseudaptinus (s. str.)]. Liebke 1934: 373, 379-380. Type from Misiones Prov. in BRC; 1 cotype from [Santa Fe Prov.]: Rosario, leg. Stevenin, in LC; fide Bruch there are other 2 ex. from the same collecting in STC.

Holot. glued to a card, Misiones: S. Ignacio, "Type" on pink paper; "Pseudaptinus / mimicus Lbk. / Type M. Liebke determ." handwr. by Liebke, ex BRC.

minus [Barypus]. Roig-Junent 1993a: 99-101, f. 8, 19, 27, 35, 99-107. 1 o $^{7}$ parat. without locality label. Holot. $0^{*}$, allot. $q$ and parat. from Neuquen Prov.: Lolog, in MLP; other parat. in IAD and IPCN.

10 parat. glued to a pointed card, with a glass microvial, without locality label.

Note: Included by Roig-Junent (1993b) in Barypus (Cardiophthalmus).

mirasoi [sub Mirasoi] [Bembidium]. JensenHaarup 1910; 552. Mendoza Prov.: Pedregal, "very few specimens".

3 synt. glued to cards, Mendoza Prov., "Cotypus" on pale green paper; one of them, in addition, "Bembidium/Mirasoi/J.-Hrp." handwr. by Bruch, ex BRC.

Notes: Recorded under Bembidion by Blackwelder (1944: 29), and under Notaphus (s. str.) by Jeannel (1962: 624,625). Perhaps a synonym of Notaphus laticollis (Brullé 1838). montoroi [sub Montoroi] [Lachnophorus]. Tremoleras 1931: 247-248. Many ex, including the type, from Uruguay: Flores, and Florida, in TC.

6 parat. glued to pointed cards, on 3 pins, Uruguay: Florida, and Flores, "Para-/ typus" handwr. on red paper; "Lachnophorus / Montoroi / Trmls / Juan Tremoleras det." handwr. by Tremoleras, ex BRC.

neuquensis [Barypus]. Roig-Junent 1993a: 93-94, $\mathrm{f}$. $3,14,22,30,54-62.10$ parat. Neuquen Prov: San Martín de los Andes: Chapelco. Holot. $\sigma^{*}$, allot. $Q$ in IPCN; parat. in MLP, IAD and MHNS.

1 parat. glued to a pointed card, with a glass microvial, Neuquen: S. Martín de los Andes: Chapelco.

Note: Included by Roig-Juñent (1993b) in Barypus (Cardiophthalmus).

neuquensis [Cnemalobus]. Roig-Juñent 1993c: 299300, f. $15,24,43,46,47,53$. Parat. Neuquen Prov: $20^{7}$ Collon-Curá, 1 o Bajada Maruchoł Río Negro Prov: 1 o Cerro Alto. Holot. $0^{*}$, Neuquen Prov.: Rinconada, allot. O Neuquen Prov.: Aluminé Lake, both in MLP. Other parat in IAD and IPCN.

2 parat. $0^{*}$, Neuquen Prov.: Collon Cura; $1 \%$, Neuquen Prov.: Bajada Marucho; 10 Rio Negro Prov.: Cerro Alto, with a glass microvial; all pinned.

nuria [Cnemalobus]. Roig-Junent 1994: 11-13, f. 21, $35,43,44,56,60.1$ parat. Chile: Coquimbo Region: Tongoy Guanaqueros. Holot. $\sigma^{7}$, allot. $O$ idem. in MHNS. Other parat. in MFNS, MLP and IAD.

1 parat., pinned, with a glass microvial, Chile: Tongoy Huanaquera.

oglobini (sic) [Colliuris (Odacanthomimus)]. Liebke 1938: 74n75, f. 45. 2 ex. Misiones Prov: Loreto, type in LC, cotype in BRC.

1 parat. glued to a card, Misiones: Loreto, "Cotypus" handwr, by Bruch on pale green paper; "Colliuris / Ogloblini / Liebke" handwr. by Bruch, ex BRC.

Note: The species was named in honour of Dr. A. A. Ogloblin. The name should have been spelled ogloblini.

orfilai [Callidula]. Mateu 1954: 6, 7-8. Type o' from Río Negro Prov: Moreno Lake. Cotype $\odot$ in JMC.

Holot. glued to a card, dissected parts glued to a further card, R. Negro: Moreno Lake, "Tipo" on red paper; "Callidula / orfilai mihi / J. Mateu det." handwr. by Mateu, ex BRC. Slide P.00173, sub C-66 in slide collection.

Note: Currently included in Chaudoirina (Nègre, 1973). 
ovipennis [Apenes]. Liebke 1936a: 300-301. Type from Mendoza Prov. in BRC, 1 ex from San Luis Prov.; ex BRC in LC.

Holot., pinned, Mendoza Prov., "Cotypus" on red paper; "Apenes / ovipennis Lbk. Kotype / M. Liebke, determ." handwr. by Liebke, ex BRC.

painensis [Barypus]. Roig-Juñent \& Cicchino 1989: 209-210, f. 1, 7, 18, 27, 36, 71-19. $10^{7}$ parat. from Santa Cruz Prov, ex BRC. Holot. $0^{*}, 10^{*}, 1 \%$ parat. from Chile: El Paine Nation. Park, in IPCN; other parat. in MLP and FIML.

$10^{x}$ parat., pinned, with a glass microvial, S. Cruz Prov. ex BRC.

Note: Included by Roig-Juñent (1993b) in Barypus (Cardiophthalmus).

passosi [Paussus [(Paussus)]]. Luna de Carvalho 1964: 87-88, f. 1. Holot. O Angola: Caluango: Caquele River, in $M D$, parat. in $M D, R C$ and $\mathbf{L C C}$.

1 parat. glued to a card, "Ang. 16296.1", "Paratipo" on pale pink paper; "Paussus / passosi /L. de Carv," handwr. on pale pink paper, ex MC.

patagonica [Chaltenia]. Roig \& Cicchino 2001: 664666, f. 3, 8-27. 1 parat. Santa Cruz Prov: Túnel Valley; 1 parat. Buenos Aires Prov: Bajo Hondo. Holot. $\sigma^{\circ}$, allot. O Santa Cruz Prov: Túnel Valley, in MLP; 1 parat. B. Aires Prov: Bajo Hondo, in IAD.

1 parat, pinned, wings unfolded, one wing glued to a card, "Valle Tunel [handwritten]/Santa Cruz [printed]" on white paper; " $q$ " handwr.; 1 parat. glued to a pointed card, a plastic microvial, "Bajo Hondo [handwritten]/ P. B. Aires [printed]" on white paper; "O" handwr; both: "Chaltenia/ patagonica" printed on white paper; a square piece of red cardboard; "Paratypus" printed on yellow cardboard.

peruvianum [Bembidium]. Brèthes 1920: 33-34. Perú: Chanchamayo.

2 synt. glued to cards, Perú, "Type!" and "Bembidium / peruvianum / Brèthes" both handwr. by Brèthes, ex JB.

Note: Recorded under Bembidion by Blackwelder (1944: 29),

piceus [Cnemalobus]. Roig-Juñent 1994:26-27, f. 10 , $11,31,61,66,83,92.1$ parat. Chile: Santiago: Palmas de Ocoa. Holot. $0^{n}$, allot. o Chile: Santiago: Cerro El Roble, in MHNS; other parat. in MCH, IAD and MIP.

1 parat. pinned, with a glass microvial, Chile: Palmar de Ocoa.

proseni [sub Proseni] [Calosoma retusum var.]. Dallas 1944: 5-6, f. 1. Salta Prov.: Maimogasta, holot. $0^{*}$ in PC; parat. of in DC.

10 parat., pinned, with a glass microvial, "Bs. Aires / 1904", "Para/Typus", handwr:; "Cálosoma/ retusum F. / var. Proseni / Dallas 1942" handwr, by Dallas?; a small, square piece of red paper, ex $\mathbf{D C}$.

Notes: The locality differs from the published one, but the remaining labels seem authentic. Vidal Sarmiento (1959: 294, f. 12-16) mentions only the species, as Castrida retusum; Gidaspow (1963: 287, 303-304, f. 7, 10, 26, 35, 47, 48, 78, 79, 88) also, as Calosoma (Castrida) retusum.

pseudochiloleuca [Cicindela Drakei subsp.]. Hom 1908: 209. \%, 7 in great amounts, Tucumán Prov: Tafi Valley, ex BRC and RIC; types in WHC.

1 parat., pinned, Tucumán Prov., "Typus" on pale green paper; "pseudochiloleuca / W. Horn type" handwr. by Horn, cut, ex BRC.

Note: Recorded as Cylindera (Plectographa) Drakei subsp. pseudo-chiloleuca by Rivalier (1954: 266).

pseudodistinguenda (Megacephala fulgida subsp.]. Horn 1905: 51-52. 0", from Santiago del Estero NW, Gran Chaco (Steinbach), and from San Luis (Bruch).

1. $0^{7}$ synt., pinned, S. Luis, "Typus" on pale green paper; "Tetracha / fulgida Klg. / var. / pseudo-distinguenda / W. Horn" handwr. by Bruch, with a red frame, ex BRC.

Note: Roig-Juñent (letter of 15.IX.2003) says it is the same as Megacephala (Tetracha) fulgida KXlug 1834.

pulchellus [Barypus]. Burmeister 1868: 225, 227.1 $\sigma^{7}$ Buenos Aires Prov: Salado River.

Holot. $0^{7}$, pinned, with a glass microvial, without labels, ex HB. On the bottom of the drawer, two labels read: "Barypus / Nob. / Baripus Dej.", "pulchellus / Nob. / Rio Salado" handwr. by Burmeister.

Note: Included by Roig-Juñent (1993b) in Barypus (Barypus).

pulchellus [Cnemalobus]. Roig-Juñent 1994: 27-28, f. $2,5,19,32,61,67,85,86,93$. Holot. $0^{\prime}$, allot. $\&$, parat. Chile: Santiago: Cantillana, in MLP; other parat. id. in IAD; Chile: Santiago: Horcón de Piedra, in MHNS; Chile: Pichi Alhue, in DZC.

2 parat., pinned, Chile: Santiago Prov: Cantillana.

puncticeps [Mimodromius]. Liebke 1935; 161-162. $8 \mathrm{ex}$. from Mendoza and Catamarca, in BRC and LC; 1 ex. from Santiago del Estero: Icaño, in MNHN.

4 synt. glued to cards: 1 Catamarca Prov.: La Ciénaga; 1 Catamarca Prov: Fuerte Quemado; 1 Catamarca Prov.: Famabalasto, and 1 Mendoza Prov., "Typus" on red paper; "Mimodromius / puncticeps / Lbk. / M. Liebke determ." handwr. by Liebke, ex BRC. 
Note: Recorded under Mimodromius (Cobosia) by Mateu (1955: 80, 97-98, f. 7, 45).

rhytidopteroides [Odontochila lacordairei subsp.]. Horn 1906: 175-176, 1 f from Formosa in BRC द many o", o ("copiose lecto") from Brasil: Mato Grosso State: Cuiabá.

1 synt. (parat.?) pinned, Formosa Prov,, "Cotypus" on pale green paper; "Odontochila/ Lacordairei Gory / subsp. thytidopte / roides m." handwr. by Horn, ex BRC.

Note: Horn (1906: 175, footnote) says he received this specimen from Bruch "nachträglich" (thereafter) for identification; it is not clear if he included it in the type series.

rugosus [Mimodromius (Cobosia)]. Mateu: 1955; 93, f. 34-36. Cotypes La Rioja Prov.: Iliar. Further ex. La Rioja Prov: Patquía, in PC; Santiago del Estero Prov: Sumampa, in JMC.

5 synt. 28922 glued to cards, on 2 pins, La Rioja Prov: Iliar, "Cotipo" on red paper; "Mimodromius / (Martinezia) / rugosus / n. sp. / J.L. Mateu det." handwr. by Mateu, ex BRC.

ryei [sub Ryei] [Bembidium]. Jensen-Haarup 1910: 551. Mendoza Prov,, "not rare".

1 synt. glued to a card, Mendoza Prov, "Cotypus" on pale green paper; "Bembidium/Ryei /J.-Hrp." handwr. by Bruch, ex BRC.

Note: Mentioned under Bembidion (incertae sedis) by Csiki (1928: 162). After Roig-Juñent (letter of 15.X.2003) the taxonomic status remains uncertain, but it is not a species of Bembidium.

steinbachi [Lachnophorus (Aretaonus)]. Liebke 1936b: 468, 468. 1 cotype from Salta in BRC. Type and 12 ex. from Bolivia: Santa Cruz: Buena Vista in LC; many other specimens seen.

1 parat. glued to a card, Salta, "Kotype" on pink paper; "Lachnophorus / steinbachi Lbk. Kotype / M. Liebke determ." handwr. by Liebke, ex BRC.

striatipennis [Cnemalobus]. Roig-Junent 1994: 2324 , f. $29,61,64,76,77,80.8$ parat. Chile: Talca: Alto Vilches. Holot. $\sigma$, allot. $\%$, parat. $i d$. in MLP; other parat. in MHNS, DZC and IAD.

8 parat., pinned, Chile: Talca Prov: Alto Vilches.

subfoveolatus [Metius]. Straneo 1951b: 79. Many ex. from Brasil: Santa Catarina State, leg. Plaumann,

$1 \%$ synt. glued to a pointed card, Brasil: [S. Catarinal: Nova Teutonia, "Metius/subfoveolatus Str. / Det. S.L. Straneo 1951 [black ink] / Paratypus [red ink]" handwr. by Straneo. sulcatipennis [Barypus]. Roig-Juñent 1993a: 95, f. $4,15,23,31,63-71$. Holot. o , allot. o, $1 \&$ parat. Neuquen. 1 \% parat. in MLP.

Holot. $\varnothing^{*}$, allot. $\&, 1 \%$ parat, glued to pointed cards, with a glass microvial, Neuquen.

Note: Included by Roig-Junent (1993b) in Barypus (Barypus).

suturalis [Mimodromius (Cobosia) lepidus var]]. Mateu 1955: 92, f. 31, 32. Catamarca Prov.: Ampayo, La Ciénaga, Cerrillos and other localities, in BRC. Type from Jujuy, in FIML.

1 \% parat., 53275, glued to a card, Catamarca: Cerrillos, "Paratipo" on red paper; "Mimodromius / (Martinezia) / lepidus / var. suturalis nov. / J. Mateu det." handwr. by Mateu. A slide "P 00205", in slide collection sub M-56.

tincta [Lebia (Loxopeza) striata var], Liebke 1936a: 303. 2 ex. Córdoba Prov. La Paz, in BRC and LC.

1. synt. glued to a card, Córdoba: S. Javier: La Paz, "Typus" on orange paper; "Lebia striata/var. tincta Lbk. / M. Liebke determ." handwr. by Liebke, ex BRC.

trimaculata [Colliuris (Odacanthella)]. Liebke 1930: 694-695. 1 ex. from Buenos Aires Prov. in BRC. Type from Brasil: Santa Catarina State: Joinville, in ZMB; 2 ex. from Brasil: Santa Catarina State, in MTD; 2 ex. from Brasil: Rio de Janeiro, in BM; 1 ex. from Brasil, in AC; 4 ex. from Brasil, in DEI.

1 parat. glued to a card, B. Aires Prov., "Kotype" on pink paper; "Odacantha/trimaculata / det. M. Liebke. Hamb." handwr. by Liebke, cut, ex BRC.

Note: Currently included in Colliuris (Apioderina) (Liebke, 1938).

tucumana [Galerita]. Liebke 1932: 41.5, 418-419.4 ex. from Tucumán, in $\mathrm{BRC}$ and $\mathrm{LC}$.

Lectot. $\sigma^{7}$, paralectot. $ᄋ$, pinned, B. Aires Prov., "Kotype" on pink paper; "Galerita/ tucumana / Kotype / M. Liebke determ." handwr. by Liebke, ex BRC.

Notes: Lectot. and paralectot., labelled "Galeritula tucumana", designated by Reichardt (1967b: 70-71, f. 50, 52), who mentions 3 further "cotipos" at Warshaw Museum, ex LC; Liebke mentioned only 4 specimens from Tucumán.

tupungatensis [Cnemalobus] Roig-Juñent 2002: 55-59, 61, f. 1, 5-7, 10, 15, tab. 6. Mendoza Prov.: Tupungato: Pampa La Carrera 12.X.1998 S. Roig leg. 2 parat in MACN. Holot. in IAD, $160^{\circ}, 20 \%$ parat. IAD, MLP, FIML; 2 parat. Mendoza Prov.: Paramillos de Uspallata in IAD.

2 parat., pinned, one of them with a plastic microvial. Mendoza Prov: Tupungato: Pampa de 
la Carrera 12.X.1998, leg. S. Roig, "Paratypus" printed on red paper; "Cnemalobus " tupungatensis / Roig-Juñent 2002" printed on white paper.

vianai [Physeomorpha . Ogueta 1963: 113-116, f. 5, 6, 8, 12. Holot. 9 Santiago del Estero Prov: Salado River, in BRC.

Holot. o glued to a card, dissected parts glued to a further card, S. del Estero: Salado River, ex BRC.

wagnerï [Mimodromius]. Liebke 1935: 160-161. 4 ex. Catamarca Prov: La Ciénaga, in BRC (types) and LC; 7 ex. Santiago del Estero Prov: Icaño, in MNHN and $\mathrm{LC}$.

2 synt. glued to cards, Catamarca Prov.: La Ciénaga, "Cotypus" on orange paper; "Mimodromius/ wagneri Lbke. / M. Liebke determ." handwr. by Liebke, ex BRC.

Note: Recorded under Mimodromius (Cobosia) by Mateu (1955: $82,93-94$, f. 37-40).

waterhousii [sub Waterhousii] [Odontoscelis]. Burmeister 1870: 126. = Odontoscelis Desmaresti: Burmeister 1868: 228. Buenos Aires Prov.: Salado River; Entre Rios Prov: banks of Uruguay River, and Paraná; Santa Fe.

3 synt., pinned: 1 "Uruguay" [probably Uruguay River is meant $1 ; 1$ B. Aires: Salado River; and $1 \mathrm{E}$. Rios: Parana. On the bottom of the drawer two labels read: "Odontosce / lis Curt. / Cnemacanth. Br." and "Waterhousii Nob. / Rep. Argent." handwr. by Burmeister. All ex HB.

Notes: Recorded as Cnemacanthus Waterhousei (sic) by Csiki (1928: 16). Synonymized with Cnemalobus striatus (Waterhouse 1841) by Roig-Juñent 1993c.

$y t u$ [Lebia (Chelonodema)]. Reichardt 1972: 32-33, f. 1-4, 10, 17, 54. 19 parat. Misiones Prov.: San Ignacio. Holot. $0^{7}$, parat. Brasil: S. Paulo State: Ytu, in MZSP; parat. from other localities ibid., MNHN, IBSP and NC.

1 \& parat., pinned, Misiones: S. Ignacio, "Lebia / (Chelonodema) / ytu, sp. n. / paratype $\& /$ Reichardt det. 1972" handwr. by Reichardt on red paper.

\section{NAMES NOT FOUND IN THE LITERATURE AND PRESUMABLY NOT PUBLISHED}

bruchi [Brachinus]. Maindron

1 ex., pinned, Jujuy, "Typus" on pale green paper, ex BRC.

donckieri [sub Donckieri] [Coptodera]. Maindron 1 ex., pinned, Brasil: Goiás State: Jatahy,
"Cotypus" on pale green paper; "Coptodera Donckieri m." handwr., cut, ex BRC.

\section{SPECIMENS LABELLED AS TYPES BUT NOT INCLUDED IN THE ORIGINAL SERIES}

argentinicus [Pseudaptinus [(Enaphorus)]]. Liebke 1929: 351, 1 f. 2 ex. Buenos Aires Prov., ex BRC, cotype in LC [ergo type in BRC].

2 ex., B. Aires Prov., "Cotypus" by Bruch, ex BRC.

Note: These specimens were not mentioned in the original publication (see the main list, above). Currently included in Thalpius.

bosqui (sic) [Mimodromius]. Mateu 1955: 97, f. 43, 44. Cotypes: Neuquen Prov: Zapala, at MACN and FIML; La Pampa Prov:: Pico, in JMC; Río Negro Prov: ChoeleChoel, and Neuquen: Plaza Huiral (sic), in PC; Buenos Aires Prov: Solá Railway Station, and Mendoza, in JMC.

1 ex. 31793, from B. Aires Prov.: San Blas, "Cotipo" on red paper; "Mimodromius / (Martinezia) / bosqui n. sp./J. Mateu det." handwr. by Mateu.

Note: The locality was not mentioned in the original publication (see the main list, above), but otherwise the labels seem authentic.

bruchi [Scarites]. Bänninger 1932: 210-211. $3 \mathrm{ex}$. Mendoza Prov: Potrerillos (type in BRC, 2 cotypes in BC); 1 ex. Catamarca Prov: La Ciénaga, in BRC; 2 ex. Mendoza, at BM; 2 ex. Tucumán, in BC.

1 ex. from Catamarca Prov: La Ciénaga, "Cotypus", ex BRC.

Note: The specimen was mentioned in the original publication, but it seems not to have been intended as a type. (see the main list, above)

confluens [Cicindela]. Horn 1893: 197-198, pl. 3: 6 . 1 \& from Brasil: Minas Gerais State.

1 ex., Formosa 1.1905, "Cotypus"; "Cic. con/ fluens W. Horn" handwr. by Horn, ex BRC.

Notes: Formosa was not mentioned in the original publication, and the specimen was taken after the publication date. Recorded as Cicindela confluente-signata by Horn (1915: 407) nom. nov. proconfluens Horn (1893) non Beuthin nec Kraatz nec Fowler; = nigrosticta Chaudoir 1865 in catal.; recorded as Cylindera confluente-signata by Vidal Sarmiento (1966b: 38).

obsoletesignata [Cicindela]. Horn 1895a: 91-92. 1 o Brasil: Santa Catarina.

1 ex., Chaco de S. Fe, "Cotypus" on pale green paper; "C. obsoletesignata" handwr. by Horn, cut, ex BRC.

Notes: The specimen was not mentioned in the original publication. Recorded as Brasiella? ob- 
soletewsignata by Rivalier (1954: 263), and as Brasiella obsoletesignata by Vidal Sarmiento (1966b: 31).

ritsemae [sub Ritsemae] [Cicindela]. Horn 1895b: 15-16. Argentina.

1 ex., Córdoba, 1906, "Cotypus" on pale green paper; "Ritsemae W. Horn", handwr. by Horn, ex BRC.

Notes: The specimen was taken after the publication date. Recorded under Cylindera (Plectographa) by Rivalier (1954: 266).

solieri [sub Solieri] [Mimodromius]. Csiki 1932: 1461. Nom. nov, pro Mimodromius pictus (Solier in Gay 1849: 141, name of Maille) non Dejean.

1 ex., Córdoba Prov.: Unquillo, 1926, "Typus" on red paper; "Mimodromius / solieri / Csiki / M. Liebke determ." handwr. by Liebke, ex BRC.

Note: This is a replacement name; this specimen is not a type.

victoriensis [Ceroglossus chilensis var.]. Dallas 1933: 75. 3 cotypes (one at 1ZG; two in DC). Name of Bodemeyer in litt., 1924, who sent these 3 'cotypes'; at the death of $B$. von Bodemeyer "... la descripción posiblemente publicó después el célebre carabólogo Dr. Roeschke en alguna revista europea" (... the description was possibly published by the celebrated carabologist, Dr. Roeschke in some european journal).

1 ex., Chile: Malleco: Victoria, ex coll. Dallas, "Contypus" on red paper; "Ceroglossus / chilensis /B. v. Bodemeyer"; "nov. var. victoriensis / B. v. Bodemeyer et Röschke" handwr. on red paper.

Notes: As of Dallas (1933) it is a nomen num dum, there is no description; if the name had in fact have been published by Roeschke, this specimen would be a syntype, or a paratype if some specimen labelled "Typus" would remain in Ger. many. Blackwelder (1944: 21) refers the name to Dallas (1933: 75). No reference to Roeschke, nor to Ceroglossus, was found in Zoological Record (1922 - 1940).

\section{BIBLIOGRAPHY}

Bänninger, M. 1927. Die Ozaenini (Col, Carab.) 10. Beitrag zur Kenntnis der Carabini. Deutsche entom. Zeitschr. 1927 (3): 177-216.

- 1932. Über Carabinae, Ergänzungen und Berichtigungen (Col). 17. Beitrag. Deutsche entom. Zeitschr. 1931 (4): 177-212.

- 1938. Monographie der Subtribus Scaritina (Col. Carab.). II. Deutsche entom. Zeitschr. 1938: 41-181.

Bates, H.W. 1871. Notes on Carabidae and descriptions of new species (№ 2). Entom. monthly Mag. 7: 244. 248.

Berg, C. 1883. Zur Pampa-Fauna, Entom. Zeitg., Stettin 44: 392-396.
Blackwelder, R.E. 1944. Checklist of the Coleopterous insects of Mexico, Central America, the West Indies, and South America. Part. 1. Bull. U. S. nat. Mus. $185(1):$ xii $+188 \mathrm{p}$.

Brèthes, J. 1916. Descripción de un nuevo carábido de la República Argentina. Physis, B. Aires 2 (12): 464465.

- 1920. Insectes du Pérou. Anls. Soc. cient. argent. 89: 27.54 .

Bruch, C. 1908. Eine neue Carabidengattung aus Argentinien Cicindis Horni (Col.). Deutsche entom. Zeitschr. 1908: 497-500.

Brullé, G.A. 1838. Insectes. In A. d'Orbigny, Voyage dans l'Amérique méridionale 2 (2): 17-56.

Burmeister, H. 1868. Bemerkungen über die Gattungen Barypus, Cardiophthalmus und Odontoscelis. Entom. Zeitg, Stettin 29 (7-9): 225-229.

- 1870. Synonymische Berichtigung (Entom. Zeit. 1868 pag. 228). Entom. Zeitg., Stettin 31: 125-126. 1875. Description of a new genus of Coleoptera, belonging to the family Scaritidae. Trans. entom. Soc., London 1875: 339-342.

- 1885. Revision der Gattung Eurysoma. Entom. Zeitg., Stettin 46: 321-333, 1 pl.

Chaudoin, M. de. 1865. Catalogue de la collection de cicindeletes de M. le baron Chaudoir: 64 p., Bruxelles.

Csiki, E. 1928. Carabidae: Mormolycinae, Harpalinae I In Schenkling, S. (Ed.) Coleopt. Catal., Berlin (97): $3+226$.

- 1929. Carabidae: Harpalinae III. In Schenkling, S. (Ed.) Coleopt. Catal., Berlin (104): 1-527.

- 1932. Carabidae: Harpalinae VII. In Schenkling, S. (Ed.) Coleopt. Catal., Berlin (124): 1279-1598.

1933. Carabidae: Harpalinae VIII. In Schenkling; S. (Ed, Coleopt. Catal., Berin (126): 1599-1933.

Dallas, E.D. 1933. Nuevas formas de coleópteros chilenos. Revta. chilena Hist. nat., Santiago, Chile 37: $74-75$,

- 1944. Diagnosis preliminar de una nueva variedad de Calosoma retusum (F), Revta. argent. Entom. 2 (4): 5-6.

Erwin, T.L. 1974. Studies of the subtribe Tachina (Coleoptera: Carabidae: Bembidini), Part II: A revision of the New World - Australian genus Pericompsus LeConte. Smithson. Contr. Zool., Washington (162): 1-96.

Freitag, R. \& B.L. Barnes, 1989. Classification of Brazillan species of Cicindela and phylogeny and biogeography of subgenera Brasiella, Gaymara new subgenus, Plectographa, and South American species of Cilindera (Coleoptera: Cicindelidae). Quaest. entorn. 25 (3): 241-386.

Gemminger, M. \& B. de Harold. 1868. Catalogus Coleopterorum 1: xxxvi +432 p., Monaco.

Gidaspow, T. 1963. The genus Calosoma in Central America, the Antilles, and South America (Coleoptera, Carabidae).Bull. Amer, Mus. nat. Hist., New York $124(7) ; 277-313$.

Horn, W. 1893. Neue Cicindeliden. Deutsche entom. Zeitschr, 1893: 197-200.

1895a. Zwölf neue Cicindeliden-Species. Deutsche entom. Zeitschr. 1895: 81.93.

$1895 \mathrm{~b}$. On a new species of the family Cicindelidae from Argentina. Nol. Leyden Mus. 17: 15 16. 
- 1905. Systematischer Index der Cicindeliden. Deutsche entom. Zeitschr. 1905 (2, Supplement): 1 . 56.

- 1906. Odontoch ila Lacordairei Gory rhytidopteroides (nov. subsp.) und über das Vorkommen verschiedener Rassen derselben Species am selben O'rt. Deutsche entom. Zeitschr. 1906: 175-176.

- 1908. Zwei neue Cicindela-Rassen der Neuen Welt. Entom. Wochenbl. 25:209-210.

- 1909. Zwei neue neotropische Megacephala (Col.). Deutsche entom. Zeitschr. 1909: 284-286.

- 1915. Coleoptera Adephaga Fam. Carabidae Subfam. Cicindelinae. In Wytsman, P. (Ed.) Genera Insectorum, Bruxelles (82): 1-486.

International Commission on Zoological Nomenclature. 1999. International Code of Zoological Nomenolam ture, $4^{\text {th }}$ ed.: $x x i x+306 p$.

Jeannel, R. 1962. Les Trechides de la Paléantarctide occidentale. In Delamare-Déboutteville, C. \& E. Rapoport (Dir.) Biol. Atnér. Austr. 1: 527 655.

Jensen-Haarup, A.C. 1910. New species of Coleoptera from West Argentina. Deutsche entom. Zeitschr. 1910: 541-554.

Kavanaugh, D.H. \& E.L. Erwin. 1991. The tribe Cicindini Bänninger (Coleoptera: Carabidae): Comparative morphology, classification, natural history, and evow lution. Proc. entom. Soc. Washington 93 (2): 356-389.

Liebke, M. 1928. Laufkäfer-Studien. V. Entom. Anz. 8: 174-177, 185-186, 189-193, 198-201, 205-209, 215$218,221-224$

- 1929. Neue Carabiden aus Argentinien und Bolivien. Physis, B. Aires 9 (34): 346-354.

- 1930. Revision der amerikanischen Arten der Unterfamilie Colliurinae (Col. Carab.). Mitt, zool. Mus. Berlin 15: 647-726.

- 1932. Die Galerita-Arten des Rio de la Plata Stromtales (Col. Carabidae). Revta. Entom, R, Janeiro 2: 415 420.

- 1933. Die amerikanischen Arten der Gattung Zuphium (Col. Carab.). Revta. Entom., R. Janeiro 3 (4): 461-472.

- 1934. Die Arten der Gattung Pseudaptinus Cast. (Col. Carabidae). Revta. Entom., R. Janeiro 4 (3): $372-388$.

- 1935. Neue Carabiden aus Süd und Mittelamerika, hauptsächlich des Pariser Museums. Rev. franç. Entom. 2: 143-177.

- 1936a. Neue Carabiden aus Argentinien (Col Carab.). Revta. Entom., R. Janeiro 6 (2): 300-304.

- 1936b. Die Gattung Lachnophorus Dejean (Col. Carabidae). Revta. Entom., R. Janeiro $6(3-4)$ : 461468.

- 1938. Denkschrift über die Carabiden-Tribus Colliurini. Festschr. 60. Geburtstag Prof. Dr. Enbrit Strand, Riga 4: 37-141.

Luna de Carvalho, 1963. Paussideos americanos (Col, Carab. Pauss.) (8ª contribuição para o estudo monográfico dos Paussídeos). Mem. Est., Mus. zool. Univ. Coimbra (283): 1-22.

- 1964. Três novos Paussideos de Angola (Col. Carab. Paussinae) (9s contribuição para o estudo monográfico dos Paussideos). Publ, cult, Comp. Diamantes Angola, Lisboa (63): 87-94.

Madge, R.B.A. 1967. A revision of the genus Lebia
Latreille in America North of Mexico (Coleoptera: Carabidae). Quaest. entom, Edmonton, Canada 3: 139-242.

Martínez, A. \& L. Jiménez-Asúa. 1965. Notas sobre Paussini sudamericanos con descripción de una nueva especie (Col. Carab.-Pauss.). Ciencia, México $23(6): 233-236$.

Mateu, J. 1954. El género Callidula Chaudoir. Revta. Soc. entom. argent. 17 (1-2): 3-8.

- 1955. Revisión de los géneros Mimodromius Chaudoir y Mimodromites Mateu (Col. Carabidae). Archiv. Inst. Aclim., Almería 4: 63-108.

- 1959. El género Cymindidius Chaudoir (Coleópteros carábidos). Bull. Inst. roy. Sci. nat. Belgique 35 (26): $1 \sim 8$.

- 1970. XII. Sur un nouveau Mimodromius (Col. Carabidae Lebiinae) des montagnes de l'Ecuador. In: Leleup, N. \& J. (ed.) Mission. Zoologique belge aux îles Galapagos et en Eauador. Inst. Royal Sci. Nat. Belgique.

Nègre, J. 1973. The zoological results of Cy. Topál's collectings in South Argentine. 24. Coléoptères: Carabidae. Folia entom hungarica 26: 289-310.

Ogueta, E. 1963. Descripciones, redescripciones y comentarios sobre Ozaenini. I. (Coleop. Carabidae). Revta. Soc. entom. argent. 26: 111-118.

- 1965a. Descripciones, redescripciones y comentarios sobre Ozaenini. II. El género Ozaena Olivier (Coleoptera, Carabidae). Physis, B. Aires 25 (69): 73 88.

1965b. Descripciones, redescripciones y comentarios sobre Ozaenini. III. El género Platycerozaena Banninger (Coleoptera, Carabidae). Physis, B. Aires 25 (70): $361-368$.

- 1966. Las especies americanas de Panagaeus Latreille, 1804 (Coleoptera, Carabidae). Physis, B. Aires $26(71): 1-13$.

- 1967. Las especies argentinas de la subfamilia Pseudomorphinae G. Horn, 1881 (Coleoptera, Carabidae). Acta zool. lilloana, Tucumán 23: 217. 232.

Peña G., L.E. \& G. Barría P. 1973. Revisión de la familia Cicindelidae (Coleoptera) en Chile. Revta. chilena Entom. 7: 183-191.

Reichardt, H. 1967a, Brachinini neotropicais; duas novas espécies e notas (Coleoptera: Carabidae). Revta. brasil. Biol. 27: 267-271.

$1967 \mathrm{~b}$. A monographic revision of the American Galeritini (Coleoptera, Carabidae). Arq. Zool., S. Paulo $15(1-2): 1-176$

- 1972. Monograph of Lebia (Chelonodema) (Coleoptera, Carabidae). Arq. Zool., S. Paulo $23(1)$ : $1-72$.

Rivalier, E. 1954. Démembrement du genre Cicindela Linné. II. Faune américaine. Rev. franç. Entom. 21: 249-268.

RoiguJuñent, S. 1993a. Revisión del género Barypus Dejean, 1828 (Coleoptera: Carabidae, Broscini). Parte II. Revta. Soc. entom. argent. 50, 1991: 89-117. 1993b. Revisión del género Barypus Dejean, 1828 (Coleoptera: Carabidae). Parte III. Revta. Soc entom. argent. 51, 1992: 1-25.

- 1993c. Las especies argentinas de Cnemalobus Guérin-Méneville 1830 (Coleoptera: Carabidae: 
Cnemalobini). Grayana, Zoot., Chile 57 (2): 285-304.

- 1994. Las especies chilenas de Cnemalobus Guérix. Méneville 1830 (Coleoptera: Carabidae: Cnemalobini). Revta. Soc. entom, chilena 21: 5+30.

- 2002. Nuevas especies de Cnemalobus (Coleoptera: Carabidae) y consideraciones filogeneticas y bibgeográficas sobre el género. Revta. Soc. entom. crgent. $61(3-4): 51-72$.

* 2003. Un género nuevo de Platynini (Coleoptera: Carabidae) de la Argentina. Revta. Soc. entom. argent. $62(1-2): 43-51$

Roig-Junent, S. \& A.C. Cicchino, 1989. Revisión del género Barypus Dejean, 1828 (Coleoptera: Carabidae: Broscini). Parte I. Boln. Soc. Biol. Concepción, Chile 60: 101-225.

Roig-Juñent, S. \& E. Scheibler. A new species of Pericompsus LeConte (Carabidae: Bembidini, rachyina) from Argentina. Coleopt.'s Bull. [accepted for publication]

Solier, A.C.C. 1849. Insectos. In C. Gay, Historia física y politica de Chile, Zoologia 4: 511 p., Paris.

Straneo, S.L. 1951a. Osservazioni sul gen. Brachygnathus Perty (Coleoptera Carabidae). Bull.
Inst. roy. Sci, nat. Belgique 27 (56): 1-8.

- 1951b. Sur la Tribu des Metinin (Antarctini auct.) (Coleoptera Pterostichidae), Rev. franç. Entom. 18: $56-88$.

- 1952. Nuovi Pterostiehini (Coleopt. Carabid.) Doriana, Genova 1 (28): 1-8.

- 1968. Considerazioni sul gen. Marsyas (Col. Carabidae) e descrizioni preliminari di nuove specie. Annls. Soc. entom. France, n. Sér. 4 (1.): 213-225.

Tremoleras, J. 1931. Deux caxabiques nouveaux de l'Uruguay. Revta. Soc. entom. argent. 3 (15): 247 248 .

Vidal Sarmiento, J. 1959. Las especies argentinas del género Castrida Motschulsky (Coleoptera Carabidae). Not. Mus. La Plata, Zool. 19 (184): 285299.

- 1966a. Valor sistemático de las estructuras genitales de las hembras en Cicindelidae (Coleoptera). Género Megacephala Latreille. Revta. Mus. La Plata, n. Ser., Zool. $9(66): 7-20$

- 1966b. Las especies argentinas de los géneros Cicindelidia Riv, Brasiella Riv. y Cylindera Westwood. Revta. Mus. La Plata, n. Ser., Zool. 9 (68): 25-46. 